日本臨床麻酔学会第 30 回大会パネルディスカッション

日臨麻会誌 Vol.31 No.5, $841 ～ 845,2011$

Context Sensitive Analgesia に基づく抗凝固療法下の術後疼痛管理（術後から退院まで）

抗凝固療法下の術後疼痛管理：下肢手術

佐倉伸一*

[要旨] 下肢関節手術の主な目的は, 疼痛緩和と運動機能回復や生活の質の向上である. しかし, 手術自体が激しい術後痛を伴い，これが術後合併症や慢性痛を引き起こす可能性がある．したがつ て, 手術の成果を向上させるためには, 適切な術後鎮痛と早期からの理学療法の実施が重要となる. 従来, 術後鎮痛法として代表的であった硬膜外鎮痛法は, 近年周術期の抗凝固療法の機会増加に伴 い, 制限されることが多くなった. 代わって，末梢神経ブロックを中心とした多様式鎮痛法を用い た積極的な周術期疼痛管理が求められている.

キーワード : 術後疼痛, 下肢手術, 多様式鎮痛法, 大腿骨頭置換術, 人工膝関節置換術

\section{はじめに}

下肢関節手術の主目的は, 運動機能の回復と疼痛 の緩和である。しかし，骨折したり機能しにくくな った骨や関節をただ人工物で置き換えるだけでは, その機能を正常化させたり疼痛を除去することはで きない ${ }^{1) 31)}$. 手術結果の向上のためには, 術後早期 離床と早期リハビリテーションによる関節運動の改 善, さらには早期回復, 早期退院, 最終的には日常 生活および社会生活への早期復帰が目標として定め られるべきである ${ }^{4)}$. . 残念ながら最新の研究 ${ }^{6}$ に よっても 1 年後の生活の質向上までは証明できてい ないが，適切な術後疼痛管理がこれらの目標達成の 助けとなる可能性がある。鎮痛によって術後早期か らの積極的な関節運動が可能となれば，周囲筋肉の 硬直化や滑膜性関節の可動性低下を防止することが できるからである。また, 術直後からの疼痛が緩和 されれば，術後痛の遷延・慢性化を予防できる可能
性があることもわかってきた ${ }^{7}$ 。一方，一概に下肢 関節手術といっても，手術の種類や医療機関(術者) によって侵襲度が異なる。したがって, 術後疼痛の 程度も一様でない。 さらに, 患者ごと, 時間経過に よっても疼痛は変化する。術前から存在していた疼 痛も術後疼痛に影響を与える。したがって, 紋切り 型の鎮痛法で，多様な術後疼痛に対処することには 限界がある，術式，患者，時間経過に合わせて対応 できる方法を目指すべきである。最小の合併症で最 大効果を上げるために, 最近では多様式鎮痛法 (multimodal analgesia)を採用することが勧められ ている ${ }^{8)}$ そそしてその中心をなすのが，現在は末梢 神経ブロックである。本稿では, 大腿骨頝部骨折に 対する大腿骨頭置換術症例 (高齢者)および変形性膝 関節症に対する人工膝関節置換術症例を例にあげ て, 未梢神経ブロックを中心とした多様式鎮痛法に よる早期疼痛管理について概説する. 


\section{I 末梢神経ブロックの利点}

下肢関節手術の術後痛は体性痛であり, 安静時痛 と体動時痛というように分けて考えることができ る。安静時痛は，鈍い不明瞭な痛みで持続的に続き C線維によって伝えられる。一方, 体動時痛は, 鋭 く局在の明瞭な痛みで, 体動後しばらくすると消失 しA $\delta$ 線維によって伝えられる。体性痛の一つは表 面の痛みで切開創の痛みである。同じ体性痛でも, 深部痛のかかわる骨・関節の痛みは強い.

オピオイドを使用した IV-PCA も下肢関節手術 に有効な術後鎮痛法である。しかし，オピオイド鎮 痛法には悪心嘔吐など合併症に関する問題点が多 く, 術後の主たる鎮痛法として用いるには問題があ る。また, $\mathrm{A} \delta$ 線維と比較して C 線維の阻害が強く 現われるため, 安静時痛には効果があるものの, リ ハビリテーション中に引き起こされる体動時痛に対 しては効果がそしい. 非ステロイド系鎮痛薬，ステ ロイドも体性痛に対しては十分な効果が期待できな い.一方, 神経ブロックは組織からの侵害刺激を直 接遮断することができるので, 安静時痛, 体動時痛 両者に対して同様な程度の効果がある。このため, 従来から下肢手術の周術期疼痛管理として腰部硬膜 外鎮痛法が積極的に用いられてきた。しかし，最近 では，以下のような点からこの鎮痛法が徐々に使用 されなくなってきている. (1)硬膜外腔への局所麻酔 薬の投与は健肢にも少なからず影響を及ぼし, 早期 離床や早期リハビリテーションの開始には不利益で あること，(2)尿閉を発生させる可能性があること， (3)近年では周術期に抗凝固療法を受け(てい) る患者 が増加し, 硬膜外血腫の発生の危険が危惧されるよ うになっていること,である。末梢神経ブロックは, これらの欠点を回避できる手段として以前から注目 されていたが，超音波診断装置の進歩に伴い超音波 ガイド下での末梢神経ブロックが平易化したこと で，多くの施設で末梢神経ブロックが硬膜外鎮痛法 に代わって，多様式鎮痛法の主たる鎮痛法として用
いられるようになった。 カテーテル挿入による持続 末梢神経ブロックは，出血による血腫や感染による 膿瘍などによって重篤な合併症を発生させる危険性 が低く ${ }^{9)}$ ，カテーテル自体の管理も簡単であること がわかっている ${ }^{10)}$.

\section{II 末梢神経ブロックの問題点}

後述するように，下肢の知覚神経支配は複雑であ り個人差も大きい，また，使用する局所麻酔薬の種 類や濃度によっては運動神経遮断も起こる可能性が ある。そのため，末梢神経ブロック単独で完全な除 痛を図ろうとすると，複数の神経ブロックを行う必 要があるばかりか，神経学的合併症(ほとんどは手 術操作や体位に起因するもの)の発見を遅らせたり, リハビリテーションの遂行を妨げる可能性もある。

\section{III 末梢神経ブロックを使用する下肢手術の 周術期疼痛管理の基本的な考え方}

周術期の疼痛は，時間経過に伴って質および程度 ともに変化する。すなわち，最大級の鎮痛効果を必 要とする術中から，術後時間が経過すれば安静時疼 痛は減少する。一方，術後時間経過とともに患者が 体動を起こし始めたりリハビリテーションを行うよ うになれば，体動時疼痛が増強する。したがって， 術中術後を通してずっと同じ鎮痛処方を使用し続け るのはナンセンスである。例えば，術中麻酔は必ず しも末梢神経ブロックだけに頼るのではなく，十分 な麻酔状態を得るために他の麻酔法を併用すること も勧められる。主眼は術後鎮痛に置くべきだろう。 特に, 最近の fast-track surgery あるいは accelerated recoveryが目標とされる下肢手術の周術期疼痛管 理をスムーズに行うためには，多様式鎮痛法を基本 にして，対象手術や患者に応じて細かく調整する必 要がある。これが下肢手術における context-sensitive treatmentということになる。

また，下肢手術患者に末梢神経ブロックを使用す る場合，単独の麻酔法として用いるのか，主たる麻 
酔法として用いるのか, 全身麻酔の補助鎮痛法とし て用いるのか, 術後鎮痛法だけに用いるのかなどに よって, 末梢神経ブロックの施行時期と使用薬剤の 種類や濃度が変わってくる。もちろん，末梢神経ブ ロックを一回投与法で行うか, 持続法を用いるかの 選択も重要である。これらは, 手術術式や外科医の 好み, 麻酔科医の好みや技量, リハビリテーション スケジュール, 手術室や病棟の適応能力, 患者自身 の希望などによって大きく影響を受ける。

なお，持続末梢神経ブロックによる除痛効果は個 人や術後経過によって異なるので, 局所麻酔薬は定 常流量注入に加えて patient controlled analgesia (PCA)によるボーラス注入で投与することが望ま しい.

\section{IV下肢の神経支配と神経ブロックの主な種類}

下肢の知覚と運動は, 主に腰神経叢と仙骨神経叢 という $2 つ の$ 神経叢によって支配されている。基本 的には，大腿の前面から内側にかけての知覚と運動 は腰神経叢によって, 臂部および大腿後面と下腿, 足部は仙骨神経叢が関与する。例外は下腿内側部で, ここは腰神経叢の枝である大腿神経の終末枝, 伏在 神経が支配している。

腰神経叢は，第 12 胸神経前枝の下半，第 1 から 第 3 腰神経前枝と第 4 腰神経の上半から構成され, 腰椎の両側で大腰筋の中に隠れている.腰神経叢は, 腸骨鼠径・腸骨下腹神経(第 1 腰神経由来), 陰部大 腿神経(第 1,2 腰神経由来), 外側大腿皮神経(第 2 腰神経単独または第 2,3 腰神経由来), 大腿神経(第 2,3 腰神経の後枝と第 4 腰神経の一部由来)，閉鎖 神経(第 $2 \sim 4$ 腰神経の前枝由来)に分か水る.

仙骨神経叢は，第 4 腰神経の下半，第 5 腰神経, 第 1,2 仙骨神経, 第 3 仙骨神経の上半で構成され, 骨盤後壁を大坐骨孔に向かって斜めに下る巨大な神 経叢である。坐骨神経は，仙骨神経叢の代表的な終 末枝の脛骨神経と総腓骨神経が合わさった最大の未 梢神経を指す。断面は卵円形で，成人では16〜
$20 \mathrm{~mm}$ の幅がある. 梨状筋の下方で大坐骨孔を通り, 臂部に出て大殿筋の下を外方に斜走し，坐骨結節と 大転子の中間点に達すると下方に向きを変える，次 いで大腿部に入り，後面ほぼ中央を大内転筋の上に 位置しながら下行する。そして, 膝窩近位で 2 本の 終末枝(総腓骨神経と脛骨神経)に分かれる。

腰神経叢が対象となる主な末梢神経ブロックに は, 腰神経叢ブロック，大腿神経ブロック，閉鎖神 経ブロックがある。一方，仙骨神経叢が対象となる のは多くの場合，坐骨神経ブロックである。坐骨神 経は最も長大な末梢神経であり，これをブロックす るためさまざまなアプローチが考案されている。こ の中で現在頻用されているのが，慰下部アプローチ と膝窩部アプローチである.

\section{$\mathrm{V}$ 症例}

\section{1. 大腿骨頭骨折に伴う人工骨頭置換術 (95 歳, 女性)}

大腿骨頝部・転子部の骨折は高齢者に多い外傷で ある．患者は全身状態が悪いことも多いが，近年で は早期 (48 時間以内) に手術を行うことが勧められ ている，施行される手術としては， $\gamma$ ネイルやCHS (compression hip screw)などによる骨接合，ある いは骨折の部位や程度により人工骨頭置換術が行わ れる。人工骨頭置換術では，大腿骨頭や大転子への アプローチとなるため切開部位は頭側に広がり, 皮 膚の神経支配を考えると末梢神経ブロック単独では 対応し難い。したがって術中麻酔法としては，脊髄 くも膜下麻酔あるいは全身麻酔を併用する。大腿骨 の神経支配は関節包内から骨頭にかけては坐骨神経 優位，関節包外から骨幹部にかけては大腿神経優位 であると考えられ，大腿神経ブロック単独でも骨折 の痛みは軽減できる。春髄くも膜下麻酔を行う際の 体位変換には強い痛みを伴うため, 仰臥位で大腿神 経ブロックを行い，効果が得られてから体位変換を 行うという方法がある。凝固能異常のある患者では, 全身麻酔を導入してから大腿神経ブロックを行って もよいだろう。大腿神経ブロックにロピバカインを 
使用すれば術後約 1 日間の疼痛緩和が得られる。そ の後は患者の訴えに応じて内服薬などで対処する. 股関節手術後は他の関節の術後ほど強い疼痛を伴わ ないので，特に本症例のように高齢者の場合には術 直後からリハビリテーションが開始される可能性も 少ないと思われる。 24 時間より後の体動時痛の軽 減について，あまり考慮する必要はない。

\section{2. 変形性膝関節症に伴う人工膝関節置換術 (65 歳, 女性)}

本手術は末梢神経ブロックが適応となる代表的な ものの一つであり, 古くからさまざまな方法が提案 されてきた。硬膜外ブロックと比較して, 未梢神経 ブロックには術後健側が動かせることや早期のリハ ビリテーションに伴う疼痛の緩和, 可動域の改善な どのメリットがあり，手技が簡単で安全性が高い. この手術において生じる痛みは主に, 皮膚切開創に 伴う膝前面の痛み，大腿骨と脛骨を削ることにより 生じる骨の痛み，ターニケットによる痛みである。 膝前面の皮膚は，主に大腿神経が支配する領域であ る.しかし, 大腿部で内側の閉鎖神経と外側の外側 大腿皮神経との境界，および下腿で坐骨神経との境 界は個人差が大きく，どの患者でも大腿神経ブロッ ク単独で完全な皮膚知覚の遮断が得られるというわ けにはいかない。閉鎖神経ブロックを組み合わせる

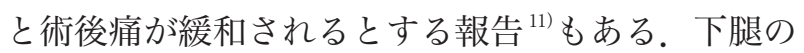
骨の知覚は主として坐骨神経支配であるため, 坐骨 神経ブロックを加えることにより鎮痛効果の増強が 見込める.

人工膝関節置換術の術後リハビリテーションのプ ロトコールは施設ごとに異なるが，おおむね翌日か ら他動での可動域訓練，続いて自動による可動域訓 練，さらに同じ頃より荷重歩行訓練が開始される. 一方, 術後に深部静脈血栓症が発生する危険性が高 いので，フォンダパリヌクスやエノキサパリンによ る抗凝固療法が術後 1 ～週間にわたつて行われ る。これらを考慮し, 術後鎮痛計画を立てる必要が ある。

術後鎮痛は大腿神経ブロックが主体となり, 術後
ただちに持続投与を開始する。手術操作によって坐 骨神経障害が発生することもあるので，持続坐骨神 経ブロックは足関節の動きを確認後開始することが 望ましい，持続坐骨神経ブロックを併用すると術後

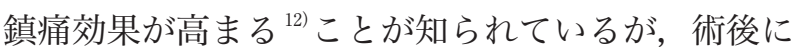
坐骨神経領域(主として膝の後面)の痛みをさほど強 く感じない患者もおり，大腿神経ブロック単独で鎮 痛が可能な場合も少なからずある。個々の症例に応 じて，持続坐骨神経ブロックを追加するとよい。た だし，使用する薬液の濃度によっては運動麻痺が顕 著となるので，転倒事故が増加したり入院期間が延 長する可能性がある ${ }^{13)}$.

抗凝固療法中にカテーテルが抜去される(を抜去 する)場合があり，持続法の安全性に関する懸念が ある。実際，大腿神経カテーテル抜去後に広範な血 腫を形成したとの報告 ${ }^{14)}$ があるが，大腿神経・坐骨 神経ブロックのように体表面に近いブロックでは, 観察と圧迫止血を徹底すれば血腫形成を回避できる 可能性が高い.

\section{結 語}

下肢手術の周術期疼痛管理は，患者の術後運動機 能改善や日常生活への復帰に大きな影響を与える可 能性がある。患者や時間経過に応じて程度や範囲が 変化する術後痛に対して，末梢神経ブロックを中心 とした多様式鎮痛法を積極的かつ柔軟に(すなわち context-sensitive treatment) 適用していくことが 望ましい.

\section{参考文献}

1) March LM, Cross MJ, Lapsley H, et al. : Outcomes after hip or knee replacement surgery for osteoarthritis. A prospective cohort study comparing patients' quality of life before and after surgery with age-related population norms. Med J Aust 171 : 235-238, 1999

2) Walsh M, Woodhouse LJ, Thomas SG, et al. : Physical impairments and functional limitations : a comparison of individuals 1 year after total knee arthroplasty with control subjects. Phys Ther 78 : 248-258, 1998 
3) Murray DW, Frost SJ : Pain in the assessment of total knee replacement. J Bone Joint Surg Br 80 : 426-431, 1998

4) Ryu J, Saito S, Yamamoto K, et al. : Factors influencing the postoperative range of motion in total knee arthroplasty. Bull Hosp Jt Dis 53 : 35-40, 1993

5) Shoji H, Solomonow M, Yoshino S, et al. : Factors affecting postoperative flexion in total knee arthroplasty. Orthopedics $13: 643-649,1990$

6) Ilfeld BM, Meyer, RS, Le LT, et al. : Health-related quality of life after tricompartment knee arthroplasty with and without an extended-duration continuous femoral nerve block: a prospective, 1-year follow-up of a randomized, triple-masked, placebo-controlled study. Anesth Analg 108 : 1320-1325, 2009

7) Perkins FM, Kehlet $\mathrm{H}:$ Chronic pain as an outcome of surgery. A review of predictive factors. Anesthesiology $93:$ 1123-1133, 2000

8) Hebl JR, Kopp SL, Ali MH, et al. : A comprehensive anesthesia protocol that emphasizes peripheral nerve blockade for total knee and total hip arthroplasty. J Bone Joint Surg Am 87A : 63-70, 2005

9) Auroy Y, Narchi P, Messiah A, et al. : Serious compli- cations related to regional anesthesia : results of a prospective survey in France. Anesthesiology 87 : 479-486, 1997

10) Swenson JD, Bay N, Loose E, et al. : Outpatient management of continuous peripheral nerve catheters placed using ultrasound guidance : an experience in 620 patients. Anesth Analg 103 : 1436-1443, 2006

11) McNamee DA, Parks L, Milligan KR : Post-operative analgesia following total knee replacement : an evaluation of the addition of an obturator nerve block to combined femoral and sciatic nerve block. Acta Anaesthesiol Scand $46:$ 95-99, 2002

12) Pham Dang C, Gautheron E, Guilley J, et al. : The value of adding sciatic block to continuous femoral block for analgesia after total knee replacement. Reg Anesth Pain Med 30 : 128-133, 2005

13) Kandasami M, Kinninmonth AW, Sarungi M, et al. : Femoral nerve block for total knee replacement - a word of caution. Knee $16: 98-100,2009$

14) Bickler P, Brandes J, Lee M, et al. : Bleeding complications from femoral and sciatic nerve catheters in patients receiving low molecular weight heparin. Anesth Analg 103 : 1036-1037, 2006

\title{
Postoperative Pain Management after Lower Extremity Surgery in Patients Receiving Antithrombotic or Thrombolytic Therapy
}

\author{
Shinichi SAKURA \\ Surgical Center, Shimane University Hospital
}

Lower extremity joint replacement is conducted to help reduce pain and improve both mobility and quality of life. However, the surgical procedures themselves also produce severe postoperative pain, which may result in postoperative complications and chronic pain. Thus, improved analgesia and physical therapy in the immediate postoperative period should be implemented to obtain improved surgical outcomes. Recently, due to the concern regarding neuraxial hematoma and bilateral motor block, peripheral nerve blocks have gained popularity and have been replacing epidural analgesia, which was once considered the technique of choice. In this paper, postoperative management with a multimodal regimen in which peripheral nerve blocks are centered is discussed.

Key Words : Postoperative pain, Lower extremity surgery, Multimodal analgesia, Hip hemiarthroplasty, Total knee arthroplasty

The Journal of Japan Society for Clinical Anesthesia Vol.31 No.5, 2011 